\title{
Energy Production During Nitrate Respiration by Aerobacter aerogenes
}

\author{
BY LIGERI P. HADJIPETROU AND A. H. STOUTHAMER \\ Laboratory for Microbiology, Catharijnesingel 59, State University, \\ Utrecht, The Netherlands
}

(Received 22 June 1964)

\begin{abstract}
SUMMARY
The molar growth yield of Aerobacter aerogenes growing anaerobically with glucose in a mineral medium was almost doubled when $\mathrm{NO}_{3}{ }^{-}$was added as hydrogen acceptor. About half a mole of $\mathrm{NO}_{3}{ }^{-}$was reduced to $\mathrm{NH}_{4}{ }^{+}$per mole of glucose. The amount of ATP produced from glucose fermentation calculated from the molar growth yield and the acetate production was about 3 moles ATP/mole glucose. The total amount of ATP produced, deduced from the molar growth yield, was used to calculate that about 3 moles ATP were produced per mole of $\mathrm{NO}_{3}{ }^{-}$reduced. Comparable experiments with mannitol as carbon source gave the same results. When nitrite was used as hydrogen acceptor the anaerobic molar growth yield was the same or even smaller than in its absence, although the acetate production increased. The results suggest that during $\mathrm{NO}_{2}{ }^{-}$ reduction no ATP is produced and that the ATP formed during reduction of $\mathrm{NO}_{3}-$ to $\mathrm{NH}_{4}{ }^{+}$is completely produced during the reduction of $\mathrm{NO}_{3}{ }^{-}$to $\mathrm{NO}_{2}^{-}$.
\end{abstract}

\section{INTRODUCTION}

The relation between energy production and growth has been studied and discussed by Bauchop \& Elsden (1960), Gunsalus \& Shuster (1961) and Senez (1962). Bauchop \& Elsden found that the growth yield per mole of ATP ( $=\mathbf{Y}^{\text {ATP }}$ ) was the same for different micro-organisms. Recently Hadjipetrou, Gerrits, Teulings \& Stouthamer (1964) found that the yield of Aerobacter aerogenes per mole of ATP produced during glucose fermentation was $10 \cdot 2 \mathrm{~g}$. By measuring the molar growth yield under aerobic conditions and the oxygen uptake during growth the molar growth yield per atom oxygen taken up $\left(=\mathbf{Y}^{\circ}\right)$ has been determined. By dividing $\mathrm{Y}^{\mathrm{o}}$ by $\mathrm{Y}^{\mathrm{ATP}}$ the number of ATP molecules formed per atom oxygen taken up is found. In this way it was found that the $\mathrm{P} / \mathrm{O}$ ratio is about three. Many facultative aerobic micro-organisms can utilize $\mathrm{NO}_{3}{ }^{-}$as ultimate hydrogen acceptor (see review by Nason, 1962). The influence of nitrate on the formation of fermentation products from glucose with Aerobacter aerogenes was studied by Forget \& Pichinoty (1964). They concluded that under anaerobic conditions in the presence of $\mathrm{NO}_{3}-$ the citric acid cycle did not function; that the production of hydrogen, ethanol and formate was decreased and the formation of acetate and $\mathrm{CO}_{2}$ increased. Until now very little has been known about the production of ATP during nitrate reduction in facultative aerobic organisms. There exists some indirect evidence (increased phosphorus turnover in resting organisms during $\mathrm{NO}_{3}-$ reduction) which suggests that in Escherichia coli and Pseudomonas denitrificans phosphorylation coupled to 
electron transport from substrate to nitrate takes place (Takahaski, Taniguchi \& Egami, 1957; Ohnishi \& Mori, 1960). Therefore we decided to study the efficiency of nitrate respiration in Aerobacter aerogenes as a continuation of our previous aerobic experiments.

\title{
METHODS
}

The minimal medium and the growth conditions were as described previously (Hadjipetrou et al. 1964). $\mathrm{NO}_{3}{ }^{-}$was determined as described by Middleton (1959), $\mathrm{NO}_{2}{ }^{-}$by the method of Rider \& Mellon (1946) and $\mathrm{NH}_{2} \mathrm{OH}$ by the method of Czáky (1948). Acetate was determined with a purified preparation of acetatekinase as described by Rose, Grunberg-Manago, Korey \& Ochoa (1954). Dry weight was estimated by measuring the extinction at $660 \mathrm{~m} \mu$ in an Unicam SP 600 spectrophotometer. From the extinction the dry weight was calculated with the previously determined relation: $\mu \mathrm{g}$. dry weight bacteria $/ \mathrm{ml} .=380 \times$ extinction at $660 \mathrm{~m} \mu$ (Hadjipetrou et al. 1964).

\section{RESULTS}

\section{Influence of nitrate on the molar growth yield with glucose and mannitol}

The molar growth yields of Aerobacter aerogenes growing: (1) anaerobically, (2) anaerobically with nitrate as hydrogen acceptor and (3) aerobically with glucose are given in Table 1. It is evident that $\mathrm{NO}_{3}{ }^{-}$increased the anaerobic molar growth yield with glucose. However, the growth yield was not as high as when $\mathrm{O}_{2}$ was the

\section{Table 1. Molar growth yields and acetate production of Aerobacter aerogenes} grown under different conditions with glucose as sole carbon source

\begin{abstract}
The glucose concentration in all experiments was $3 \mu \mathrm{moles} / \mathrm{ml}$. The nitrate concentration varied but was larger than $1.33 \mu \mathrm{moles} / \mathrm{ml}$. (see text); yields of organism are given as equivalent dry weight bacteria obtained turbidimetrically; the numbers in parentheses
\end{abstract} give the number of determinations.

$\begin{array}{lcc}\text { Growth condition } & \begin{array}{c}\text { Molar growth yield } \\ (\mathrm{g} . / \mathrm{mole} \text { glucose })\end{array} & \begin{array}{c}\text { Acetate production } \\ (\mu \text { mole } / \mu \text { mole glucose) }\end{array} \\ \text { Anaerobic } & \mathbf{2 6 \cdot 1} \pm \mathbf{0 \cdot 5 ( 1 7 )} & \mathbf{0} \cdot 84 \pm 0 \cdot 04(15) \\ \text { Anaerobic }+\mathrm{NO}_{3}{ }^{-} & 45 \cdot 5 \pm 0 \cdot 3(10) & 1 \cdot 63 \pm 0 \cdot 08(4) \\ \text { Aerobic } & 72 \cdot 7 \pm 1 \cdot 0(21) & -\end{array}$

ultimate hydrogen acceptor. In the presence of $\mathrm{NO}_{3}-$ about the same amount of fermentation occurred as in its absence (Forget \& Pichinoty, 1964): pyruvate was decomposed by a thioclastic reaction to acetyl-CoA and formate, then acetyl-CoA converted to acetate by means of phosphate acetyltransferase and acetatekinase. Thus, above the net gain of 2 moles ATP from the conversion of 1 mole glucose to 2 moles pyruvate, an additional mole of ATP is generated for each mole of acetate formed. Ethanol, which is also formed in this fermentation, is produced by reduction of acetyl-CoA (Dawes \& Foster, 1956) by the NADH produced during the formation of pyruvate. During this reduction the energy-rich bond present in acetyl-CoA is lost. The gross fermentation balance for this type of fermentation is: glucose $\rightarrow 1$ acetate +1 ethanol +2 formate. Therefore the net gain of ATP from the fermentation can only be calculated when the amount of acetate is known. The amount of acetate produced at the moment of maximal growth is included in Table 1 for the anaerobic cultures growing in the presence or in the absence of $\mathrm{NO}_{3}{ }^{-}$. It is 
evident from Table 1 that the production of acetate was much higher in the presence of $\mathrm{NO}_{3}-$ than in its absence; this confirms the results of Forget $\&$ Pichinoty (1964). In contrast to their results, however, no pyruvate accumulation from glucose under an aerobic conditions in the presence of nitrate was detected.

Similar experiments were made with mannitol as sole carbon source. Mannitol is more reduced than glucose and one oxidation step is required to convert mannitol to the hexose oxidation level. Therefore the amount of NADH produced during the conversion of mannitol to pyruvate is larger than the amount produced during the formation of pyruvate from glucose. Thus more of the acetyl-CoA is reduced to ethanol than when glucose is the carbon source. The gross fermentation balance is: 1 mannitol $\rightarrow 0.5$ acetate $+\mathbf{1 . 5}$ ethanol +2 formate. The results of the growth experiments and of the acetate determinations are given in Table 2. The molar growth yield with mannitol under anaerobic conditions was smaller than with glucose; this is in accordance with the smaller acetate production. In the presence of nitrate as hydrogen acceptor the growth yield with mannitol was larger than with glucose.

Table 2. Molar growth yield of Aerobacter aerogenes grown with mannitol as sole carbon source

The mannitol concentration was $3 \mu$ moles $/ \mathrm{ml}$. and the $\mathrm{NO}_{3}{ }^{-}$concentration $6 \mu \mathrm{moles} / \mathrm{ml}$; other data as for Table 1 .

Growth condition

Anaerobic

Anaerobic $+\mathrm{NO}_{3}^{-}$
Molar growth yield

(g./mole)

$21 \cdot 8 \pm 0 \cdot 6(5)$

$50 \cdot 6(3)$
Acetate production

( $\mu$ mole $/ \mu$ mole mannitol)

$0 \cdot 42$

$1 \cdot 07$

\section{Products of nitrate reduction}

To calculate the amount of ATP produced per mole of $\mathrm{NO}_{3}{ }^{-}$we should know how much $\mathrm{NO}_{3}-$ is reduced per mole of glucose. Therefore experiments were performed in which we studied the growth yield with a fixed amount of glucose $(3 \mu$ moles $/ \mathrm{ml}$.) and different amounts of nitrate (from 0 to $35 \mu \mathrm{moles} / \mathrm{ml}$.). The growth yield increased with $\mathrm{NO}_{3}{ }^{-}$concentrations between 0 and $1.33 \mu$ moles $/ \mathrm{ml}$, but did not change when higher nitrate concentrations were used. This suggests that at least $1 \cdot 33 / 3=0 \cdot 44 \mu$ mole $\mathrm{NO}_{3}{ }^{-}$per $\mu$ mole glucose was necessary to increase the molar growth yield from the anaerobic value to the maximum value for anaerobic growth in the presence of $\mathrm{NO}_{3}-$. Chemical estimation of nitrate revealed that indeed $0 \cdot 44$ $\mu$ mole nitrate was reduced per $\mu$ mole glucose at the moment of maximal growth. The amount of nitrite produced from this amount of nitrate was very small: only $0.06 \mu \mathrm{mole} / \mu$ mole glucose. In similar experiments with mannitol it was found that $0.93 \mu$ mole $/ \mathrm{NO}_{3}-/ \mu$ mole mannitol were needed to obtain the maximum molar growth yield for anaerobic growth in the presence of $\mathrm{NO}_{3}{ }^{-}$. The amount of nitrite produced in this experiment was $0.42 \mu$ mole $/ \mu$ mole mannitol.

These results suggest that nitrate was reduced beyond the nitrite stage; this was confirmed by the observation that larger amounts of nitrite were present before maximal growth was obtained. In this aspect our strain differs from the one used by Forget \& Pichinoty (1964) because their strain reduced $\mathrm{NO}_{3}{ }^{-}$only to $\mathrm{NO}_{2}{ }^{-}$.

In the supernatant fluid no hydroxylamine was detected and, as expected, $\mathrm{NO}_{3}{ }^{-}$ was not reduced to such gaseous products as $\mathrm{N}_{2}$ or $\mathrm{N}_{2} \mathrm{O}$. That $\mathrm{NO}_{3}^{-}$- was reduced to 
$\mathrm{NH}_{4}{ }^{+}$was confirmed by observing that our Aerobacter aerogenes grew in a minimal medium with $\mathrm{NO}_{3}{ }^{-}$as sole nitrogen source. The molar growth yields are given in Table 3. Under aerobic conditions the molar growth yield with $\mathrm{NO}_{3}{ }^{-}$as sole nitrogen source was much smaller than with $\mathrm{NH}_{4}{ }^{+}$as nitrogen source; a similar observation was made by Pichinoty (1960). Under anaerobic conditions nearly the same yield of organism was obtained in a medium with $\mathrm{NH}_{4}+$ as $\mathrm{N}$-source and $\mathrm{NO}_{3}-$ as hydrogen acceptor, as in the medium with $\mathrm{NO}_{3}{ }^{-}$as combined nitrogen source and hydrogen acceptor. These results confirm that $\mathrm{NO}_{3}{ }^{-}$is reduced to $\mathrm{NH}_{4}{ }^{+}$.

Table 3. Molar growth yields of Aerobacter aerogenes grown with $\mathrm{NO}_{3}^{-}$ as sole nitrogen source and glucose as sole carbon source

The glucose concentration in these experiments was $1.5 \mu \mathrm{moles} / \mathrm{ml}$; nitrate concentration $35 \mu$ moles $/ \mathrm{ml}$. Other data as for Table 1.

Molar growth yield

Growth conditions (g./mole glucose)

$\begin{array}{ll}\text { Aerobic } & \mathbf{5 2} \\ \text { Anaerobic } & \mathbf{4 3}\end{array}$

Table 4. Molar growth yield and acetate production of Aerobacter aerogenes grown anaerobically with glucose as sole carbon source and with various concentrations of nitrite as hydrogen acceptor

The glucose concentration in these experiments was $3 \mu$ moles $/ \mathrm{ml}$. Other data as for Table 1.

$\begin{array}{ccc}\begin{array}{c}\text { Nitrite concentration } \\ (\mu \text { moles/ml. })\end{array} & \begin{array}{c}\text { Molar growth yield } \\ \text { (g./mole glucose) }\end{array} & \begin{array}{c}\text { Acetate production } \\ \mu \text { moles } / \mu \text { mole glucose }\end{array} \\ 0 & 26 \cdot 1 & 0 \cdot 84 \\ 0 \cdot 5 & 27 & 1 \cdot 2 \\ 1 & 24 \cdot 5 & 1 \cdot 58 \\ 1 \cdot 5 & 22 \cdot 4 & 1 \cdot 6 \\ 2 \cdot 6 & 20 \cdot 6 & \text { Not determined } \\ 5 & 16 & \text { Not determined } \\ 10 & \text { No growth } & \end{array}$

The influence of nitrite on the molar growth yield with glucose

The previous results suggested that the production of some ATP by our Aerobacter aerogenes was coupled to the reduction of $\mathrm{NO}_{3}-$ to $\mathrm{NH}_{4}{ }^{+}$. To know to which step in this reduction the ATP production was coupled, experiments were made in which $\mathrm{NO}_{2}^{-}$was used as ultimate hydrogen acceptor. $\mathrm{NO}_{2}^{-}$was very toxic to the bacteria, especially when there was no other hydrogen acceptor $\left(\mathrm{O}_{2}, \mathrm{NO}_{3}^{-}\right)$present. A similar phenomenon was observed for $A$. aerogenes by Lewis \& Hinshelwood (1948). The growth yield and the acetate production with different amounts of nitrite are given in Table 4; acetate production was increased in presence of $\mathrm{NO}_{2}^{-}$ indicating that it indeed acted as hydrogen acceptor. About $0.3 \mu$ mole $\mathrm{NO}_{2}-$ were reduced per $\mu$ mole glucose, independent of the initial $\mathrm{NO}_{2}^{-}$concentration. Although the acetate production increased, the molar growth yields were similar to or smaller than those obtained in the absence of $\mathrm{NO}_{2}{ }^{-}$and decreased as the $\mathrm{NO}_{2}{ }^{-}$concentration was increased. This effect was undoubtedly due to growth inhibition by $\mathrm{NO}_{2}^{-}$. In experiments in which $\mathrm{NO}_{2}{ }^{-}$was added to a complete medium with $\mathrm{NH}_{4}{ }^{+}$as $\mathrm{N}$ - 
source and the organisms were grown under aerobic conditions, we also found a lower growth yield. A similar decrease in growth yield was obtained when, under anaerobic conditions, a mixture of $35 \mu$ moles $\mathrm{NO}_{3}{ }^{-}$and $0.5 \mu$ mole $\mathrm{NO}_{2}{ }^{-}$was used as hydrogen acceptor. Our strain could also utilize $\mathrm{NO}_{2}^{-}$as sole $\mathrm{N}$-source. The yields of organisms are given in Table 5; they are much smaller than when $\mathrm{NO}_{3}{ }^{-}$ was used as sole $\mathrm{N}$-source (compare Table 3 ). In all these experiments the growth rate was decreased by the presence of $\mathrm{NO}_{2}{ }^{-}$. The results indicate that the growth yield was decreased at lower growth rates.

Table 5. Molar growth yield of Aerobacter aerogenes grown with $\mathrm{NO}_{2}^{-}$ as sole nitrogen source and glucose as sole carbon source

The $\mathrm{NO}_{2}-$ concentration in both experiments was $5 \mu \mathrm{moles} / \mathrm{ml}$.; glucose concentration $3 \mu \mathrm{moles} / \mathrm{ml}$.

$\begin{array}{cc}\text { Growth condition } & \begin{array}{c}\text { Molar growth yield } \\ \text { (g./mole glucose) }\end{array} \\ \text { Aerobic } & 39 \\ \text { Anaerobic } & 16\end{array}$

\section{DISCUSSION}

$\mathrm{Y}^{\Delta \mathrm{AP}}$ was calculated from the results of Table 1 (Hadjipetrou et al. 1964) to be $\mathrm{Y}_{\mathrm{glp}}^{\mathrm{ATP}} \mathrm{P}=\mathbf{1 0 \cdot 2}$. This value was used to calculate the ATP yield from growth yields under anaerobic conditions in the presence of nitrate, by dividing it into the molar growth yield with nitrate. In this way we find that $45 \cdot 5 / 10 \cdot 2=4 \cdot 46$ moles ATP were produced. Hadjipetrou et al. (1964) showed that the carbon content of the Aerobacter aerogenes is $40 \%$, hence $45.5 \mathrm{~g}$. glucose were converted to cell material and $180-4.5 \cdot 5=134.5 \mathrm{~g}$. were fermented. As the net gain of ATP/mole glucose transformed to pyruvate is 2 moles and as one extra mole is formed per mole of acetate, the amount of ATP formed during fermentation of one mole of glucose was $2(134 \cdot 5 / 180)+1 \cdot 63=3 \cdot 12$ moles of ATP. From the growth yield we find that the total production of ATP was $4 \cdot 46$ moles, therefore $4 \cdot 46-3 \cdot 12=1 \cdot 34$ moles of ATP must have been produced by phosphorylation coupled to nitrate reduction. The amount of nitrate used as hydrogen acceptor during the fermentation of glucose was $0 \cdot 44 \mu$ mole $/ \mu$ mole glucose. Thus the reduction of 1 mole of $\mathrm{NO}_{3}{ }^{-}$gave $(1 / 0 \cdot 44) 1 \cdot 34$ $=3.0$ moles of ATP.

From the growth and acetate yields after anaerobic growth with mannitol, we can calculate that $Y_{\text {mannitol }}^{\mathrm{ATP}}=\mathbf{1 0 \cdot 0}$. This is in good agreement with $\mathrm{Y}_{\mathrm{glucose}}^{\mathrm{ATP}}(\mathbf{1 0 \cdot 2})$ and $\mathrm{Y}_{\text {fructose }}^{\mathrm{ATP}}(\mathbf{1 0} \cdot \mathbf{6})$ determined by Hadjipetrou et al. (1964). The molar growth yield for anaerobic growth in the presence of $\mathrm{NO}_{3}-$ was larger with mannitol than with glucose. In the same way as for glucose we can calculate that during anaerobic growth with mannitol $\mathbf{2} \cdot \mathbf{4 6}$ moles of ATP must have been produced by phosphorylation coupled to nitrate reduction, which is much more than when glucose is the growth substrate. As mannitol is more reduced than glucose more $\mathrm{NO}_{3}$ - is needed per mole of mannitol $\left(0.93\right.$ mole $\mathrm{NO}_{3}-/$ mole mannitol $)$. From the mannitol results we find that $2 \cdot 46 / 0 \cdot 93=\mathbf{2} \cdot 6$ moles of ATP are produced per mole of $\mathrm{NO}_{3}{ }^{-}$, which is in good agreement with the value of $\mathbf{3 \cdot 0}$ found for glucose.

The growth with $\mathrm{NO}_{3}{ }^{-}$as sole nitrogen source shows that $\mathrm{NO}_{3}-$ is reduced to $\mathrm{NH}_{4}{ }^{+}$. It is likely that ATP production is not coupled to the reduction of $\mathrm{NO}_{2}{ }^{-}$to $\mathrm{NH}_{4}{ }^{+}$, since no increased growth yield was obtained with $\mathrm{NO}_{2}^{-}$as a hydrogen 
acceptor (Table 5). That $\mathrm{NO}_{2}{ }^{-}$acts as a hydrogen acceptor follows from the increase in acetate production. This increase implies that an increase in growth yield might have been expected. Instead, the molar growth yields were similar to or even smaller than those obtained in the absence of $\mathrm{NO}_{2}{ }^{-}$. The explanation for this phenomenon is that in the presence of nitrite the growth rate is decreased by the growth inhibitory properties of $\mathrm{NO}_{2}^{-}$. When the growth rate is decreased part of the ATP may be dissipated, which explains the lowered molar growth yields.

Thus it is most likely that the formation of three ATP molecules is coupled to the reduction of $\mathrm{NO}_{3}{ }^{-}$to $\mathrm{NO}_{2}{ }^{-}$, indicating that the hydrogen from $\mathrm{NADH}$ produced during fermentation is transferred to nitrate in several steps and that cytochromes are involved. Several schemes in which cytochromes are involved in nitrate reduction were given by Nason (1962). Nitrite and the other intermediates of nitrate reduction were most probably reduced directly by NADH. Several such enzymes have been reported present in a number of micro-organisms (Nason, 1962).

The authors are very grateful to Professor Dr P. G. de Haan for stimulating discussions.

\section{REFERENCES}

BAUChop, T. \& ElsDEN, S. R. (1960). The growth of micro-organisms in relation to their energy supply. J. gen. Microbiol. 23, 457 .

CzÁky, T. Z. (1948). On the estimation of bound hydroxylamine in biological materials. Acta chem. scand. 2, 450.

Dawes, E. A. \& Foster, S. M. (1956). The formation of ethanol in Escherichia coli. Biochem. biophys. Acta, 22, 253.

Forget, P. \& Pichinoty, F. (1964). Influence de la respiration anaérobie du nitrate et du fumarate sur le métabolisme fermentaire d'Aerobacter aerogenes. Biochim. biophys. Acta, 82, 441 .

Gunsalus, C. \& Shuster, C. W. (1961). Energy-yielding metabolism in bacteria. The Bacteria, 2, 1. New York and London: Academic Press.

Hadjipetrou, L. P., Gerrits, J. G., Teulings, F. A. G. \& Stouthamer, A. H. (1964). Relation between energy production and growth of Aerobacter aerogenes. J. gen. Microbiol. 36, 159.

Lewis, P. R. \& Hinshelwood, C. N. (1948). The growth of coliform bacteria in media containing nitrate and nitrite. 1. Adaptation to growth with nitrate and nitrite as nitrogen sources. J. chem. Soc. p. 824.

Middetes, K. R. (1959). The use of the orange I method for determining soil nitrates and a comparison with the phenol-sulphonic acid method for soils of N. Nigeria. J. Sci. Fd Agric. 10, 218.

Nason, A. (1962). Symposium on metabolism of inorganic compounds. II. Enzymatic pathways of nitrate, nitrite and hydroxylamine metabolisms. Bact. Rev. 26, 16.

OHNisH, T. \& MoRI, T. (1960). Oxidative phosphorylation coupled with denitrification in intact cell systems. J. Biochem. (Tokyo), 48, 406.

Pichinoty, F. (1960). Réduction assimilative du nitrate par les cultures aérobies d'Aerobacter aerogenes. Influence de la nutrition azotée sur la croissance. Folia Microbiol. Delft, 5, 165.

Rider, B. F. \& Mellon, M. G. (1946). Colorimetric determination of nitrites. Indust. Engng Chem. (Anal.), 18, 96.

Rose, S. A., Grunberg-Manago, M., Korey, S. R. \& Ochoa, S. (1954). Enzymatic phosphorylation of acetate. J. biol. Chem. 211, 737.

SENEz, J. C. (1962). Some considerations on the energetics of bacterial growth. Bact. Rev. 26, 95.

Takahaski, H., Taniguchi, S. \& Egami, F. (1957). Nitrate reduction in aerobic bacteria and that in Escherichia coli coupled in phosphorylation. J. Biochem. (Tokyo), 43, 223. 